\title{
Perspective
}

Expert insights on a timely policy issue

\section{How the Current Conflicts Are Shaping the Future of Syria and Iraq}

\author{
Brian Michael Jenkins
}

(

hree previous RAND papers by the author have examined the different dimensions of the current conflict in Syria. The first of these addressed the dynamics of Syria's civil war, specifically the evolution of the armed opposition to the Assad government and the consequences of the government's counterinsurgency strategy. The second essay looked at the schism within the jihadist component of the armed opposition and compared it to schisms in other armed groups. The third examined the threat posed by the thousands of foreign fighters attracted to the jihadist formations in Syria and Iraq and looked at the record of Americans who had sought training from or wanted to join jihadist groups abroad.

This essay examines how the dynamics of the continuing conflicts will shape the future of Syria, Iraq, and the broader region. The conclusions point to a substantial gap between American national objectives and a realistic appreciation of the situation.
The continued fighting has seen the diminishing strength of Syria's secular rebels and the ascent of its most extreme jihadist component, represented by the Islamic State of Iraq and the Levant (ISIL). Despite open warfare with other rebel formations in Syria, ISIL was able to seize control of much of eastern Syria and western Iraq, which prompted American bombing. This soon expanded into a broader bombing campaign by a coalition of Western and Middle Eastern nations. As a result, ISIL has suffered some military setbacks and lost territory, but it also has been able to capture several more key cities in Iraq and Syria, and it continues to attract a large number of foreign fighters. The threat they pose, along with ISIL's continued exhortations to its supporters abroad to carry out terrorist attacks, has increased pressure on the United States to deploy American ground combat forces.

The conflicts in Syria and Iraq now seem to be at a stalemate. Towns may fall or be recaptured, but "front lines" move only mar- 
ginally. The insurgents in Syria and Iraq will not be able to overthrow the governments in Damascus and Baghdad, but neither will the Syrian or Iraqi governments be able to restore their authority throughout their national territories.

Sectarian and ethnic divisions are now almost entirely driving the conflicts. At the same time, internecine conflicts continue among the jihadists and other religiously motivated rebel formations.

National armies have failed. Power has shifted to militias. These are capable of defending ethnic and sectarian enclaves but are limited in their ability to conduct strategic operations beyond their home ground. This shift will, in turn, weaken central government authority.

Syria and Iraq are now effectively partitioned, and these partitions are likely to persist. The Kurds are consolidating their territory, uniting their enclaves in Syria and Iraq, and laying the foundation for a future independent state, although they have not announced that intention. Although the Kurds are proving to be effective fighters when supported by coalition bombing, they are unlikely to advance into traditional Sunni areas. The Syrian government has largely abandoned the Sunni areas of the country and is increasingly devoted to defending its sectarian bastion in western Syria. The Shia-dominated government in Baghdad has not been able to win over many of Iraq's Sunnis, and that will impede its ability to recapture the cities and towns now held by ISIL. Whether ISIL, despite the bombing campaign and some pressure from Iraqi forces, will be able to consolidate its Islamic State and become the primary political expression of Sunnis in Syria and Iraq or, instead, a Sunni badlands will emerge where warfare between armed rivals continues indefinitely, remains to be seen.
The fighting is likely to continue for the foreseeable future. The contest has become less political and more existential for its participants. Yearnings for peace may be universal, but none of the belligerents can imagine surviving under rule by their foes. Indeed, the fighting has gone beyond political aims and has become an engrenage, the engaging of cogs in a wheel, where warfare becomes a self-perpetuating mechanistic cycle of violence and revenge.

Foreign powers in the region and beyond have significant stakes in the conflicts, but absent large-scale direct military interventions, which can easily backfire, none of the foreign powers can guarantee the triumph of their local allies or ensure the defeat of their foes. Moreover, the interests of the external powers compete with rather than complement each other.

At a recent security conference in Aspen, Colorado, panelists representing the U.S. and Iraqi governments were asked to ponder the "question of whether the admittedly brutal stability of the Saddam Hussein regime in Iraq and the pre-revolutionary Assad regime in Syria were more in line with American interests and whether, as a consequence, the best outcome now is as close to the status quo ante as possible." ${ }^{1}$ However, the discussion took a different direction. Whatever view one may have, restoration of the status quo ante bellum is no longer possible.

Foreign fighters continue to head for Syria to join jihadist fronts, mainly ISIL, which advertises the opportunity to build an authentic Islamic State and opportunities for unlimited violence. Although the immediate threat posed by the foreign fighters may be exaggerated by those arguing for more direct military intervention, foreign fighters will continue to pose an additional layer of threat to neighboring states and countries of origin. The volume of 
individuals wanting to join ISIL or returning from Syria and Iraq is overwhelming authorities in Europe.

The conflict in Syria has produced millions of refugees on a scale close to that of Europe during World War II. As long as the fighting continues, as it seems likely to, these refugees will not be able to go home, nor can so many be absorbed by the surrounding countries. They will remain an international burden and a source of regional instability.

To summarize, the conflicts in Syria and Iraq are at a stalemate, and sectarian and ethnic divisions are increasingly driving them. The large standing armies of Syria and Iraq cannot suppress the challenges to their authority, and power has shifted to the militias. The partitions in both countries will persist, and national unity will not easily be restored. The future of Sunnis under domination of the Islamic State, the Assad regime, or Shias in Baghdad or as an independent entity remains uncertain. It must be accepted that the fighting will continue, and without a significant military investment, foreign powers (with the possible exception of Iran) are at the margin. The thousands of foreign fighters attracted to jihadist banners pose a long-term threat, and the millions of refugees generated by the conflicts will not be able to return as long as the violence continues. These stark conclusions hardly seem to be controversial, yet they are antithetical to American policy.

The very idea of a military stalemate lasting years_-or decades-defies America's sense of progress. Secular, democratic governance and religious tolerance are deeply held American values. The United States operates on the presumption that the sectarian and ethnic divisions can be bridged; that Iraq's national army can be rebuilt into an effective fighting force; that the Assad regime can be replaced by a more inclusive government; that the Sunnis can be won over and the jihadists can be isolated, contained, and defeated; that peace and national unity can be restored, enabling the refugees to return, and that this can be achieved without the commitment of large numbers of combat forces or even with the commitment of American combat forces. Unquestionably, these are noble aims, and diplomats must be optimists. Nonetheless, national objectives must be based upon realistic assessments of the situation. Here, the distance between presumed aspiration and reality seems great.

\section{The Fighting in Syria and Iraq Since 2013}

In a recent series of RAND papers and a number of shorter essays, I have endeavored to discern the underlying dynamics of Syria's civil war, the concurrent conflict in Iraq, the schism within the jihadist movement between al Qaeda and the Islamic State, and the terrorist threat posed by the foreign fighters who have joined the jihadist groups participating in these conflicts. ${ }^{2}$ The Dynamics of Syria's Civil War covered events up to 2014. This paper, the fourth in a quartet, begins with the fighting in 2014 and considers how these dynamics will shape the future of the conflict and the region. It is an appreciation of the situation without policy prescriptions, although it does raise some questions about the presumptions upon which current American strategies are based and alternatives are offered. ${ }^{3}$

Attempting to condense the multiple trajectories of interconnected conflicts over a period of a year and a half into a few pages requires going through at a gallop. It necessitates brazen simplification and ruthless pruning, but it is a useful exercise, forcing us to look beyond the often-confusing daily headlines to catch the sweep 
of events. It tells us not only about broader trends but also about the pace of change. And it warns us about the limits of predictability and the likelihood of surprises.

\section{The Ascent of ISIL}

By January 2014, open fighting had broken out between the forces of Jabhat al-Nusra (JAN), al Qaeda's affiliate in Syria, and those of the Islamic State of Iraq and the Levant (ISIL), al Qaeda's former affiliate in Iraq. ISIL is also called the Islamic State of Iraq and Syria (ISIS), or Daesh (its acronym in Arabic, in which Syria is referred to as "al-Sham"- simply, "the North"). This group, which had already demonstrated that it was clearly a rising star in the jihadist firmament and a growing power on the field in Syria, defied al Qaeda's leadership; brutally killed Sunnis who refused to bow to its interpretation of Islam, innocent Shias whom it viewed as apostate, and any non-Muslims who rejected its version of Sharia law; and carried out indiscriminate bombings in Iraq that resulted in thousands of deaths. As its acronym indicates, ISIL intended to dominate the region and impose its self-proclaimed caliphate over the territories of Iraq and throughout the Levant.

Despite its battles with JAN and other rebel formations in Syria, ISIL was able to escalate its operations in Iraq. Terrorist

\section{Despite its battles with JAN and other rebel formations in Syria, ISIL was able to escalate its operations in Iraq.}

and insurgent attacks there, which had steadily declined since 2008, began to rise in the summer of 2011 as U.S. forces began to leave the country. Growing anger at the poor treatment of Sunnis by the Shia-dominated government in Baghdad gave diehard Sunni insurgents and jihadists a constituency to exploit. Violence continued to increase in 2012 and 2013, indicating the growing strength of the resistance. Although it had been given sanctuary in central and eastern Syria by the regime of Bashar al-Assad since 2004, in 2011 ISIL turned on its previous benefactor and collaborated with other Sunni militants to depose Assad.

In January 2014, ISIL forces seized the city of Fallujah and entered Ramadi and other towns in Anbar Province, which had been an insurgent stronghold during the Iraq War. Iraqi government forces were able to retake much of Ramadi, but ISIL held Fallujah. In June 2014, ISIL forces swept across northern Iraq, seizing Samarra on June 5, 2014; Mosul, Iraq's second-largest city, on June 10; and Tikrit on June 11. ISIL continued to move northeast until its advance was stopped just 25 miles southwest of the Kurdish capital of Erbil in August. In the latter part of June, ISIL's fighters captured a number of towns on the border and key roads between Syria and Iraq, enabling its forces to more easily move back and forth between the two countries.

A name change by ISIL indicated even loftier aims: On June 29, it declared itself to be the Islamic State, a worldwide caliphate that insisted on its military, religious, and political authority over all Muslims worldwide. ISIL's leader, Abu Bakr al-Baghdadi, announced himself to be the caliph. He would answer only to God. From all others, he demanded obedience. It was an audacious assertion that most Muslim religious authorities would oppose and most Muslims would ignore but that would 
nevertheless excite and embolden Islamist extremists from England to Indonesia.

\section{Shock and Awe in Reverse}

ISIL continued its military offensive in Iraq through July and August 2014, driving Kurdish Pesh Merga militiamen back from the towns of Zumar and Sinjar and scattering thousands of Yazidi and Christian refugees across the desert. The specter of ISIL's unimpeded advance and the likely imminent slaughter of fleeing Yazidis, viewed as infidels by ISIL, prompted U.S. bombing of advancing ISIL forces on August 8, 2014.

ISIL's success on the ground, highlighted in its parades of captured military vehicles and pickup trucks filled with black-clothed fighters and its videos of mass executions, crucifixions, and beheadings of hostages - all wartime propaganda aimed at elevating the group over its rivals and attracting the most determined recruits to its banner-seemed to have unnerved U.S. officials. The rhetorical response was extraordinary: ISIL is an "imminent threat to every interest we have, ...” warned Secretary of Defense Chuck Hagel, "beyond anything we've seen. We must prepare for everything." Attorney General Eric Holder said that ISIL was "more frightening than anything I've seen as attorney general." 5 Oklahoma Senator Jim Inhofe asserted, "We are in the most dangerous position we've ever been in as a nation." ${ }^{6}$ Departing from any evidence, some pundits and politicians lurched into lurid scenarios, warning that it was "highly probable" that ISIL would "obtain nuclear, chemical,

Figure 1. Civil war in Syria and Iraq, June 24, 2014.

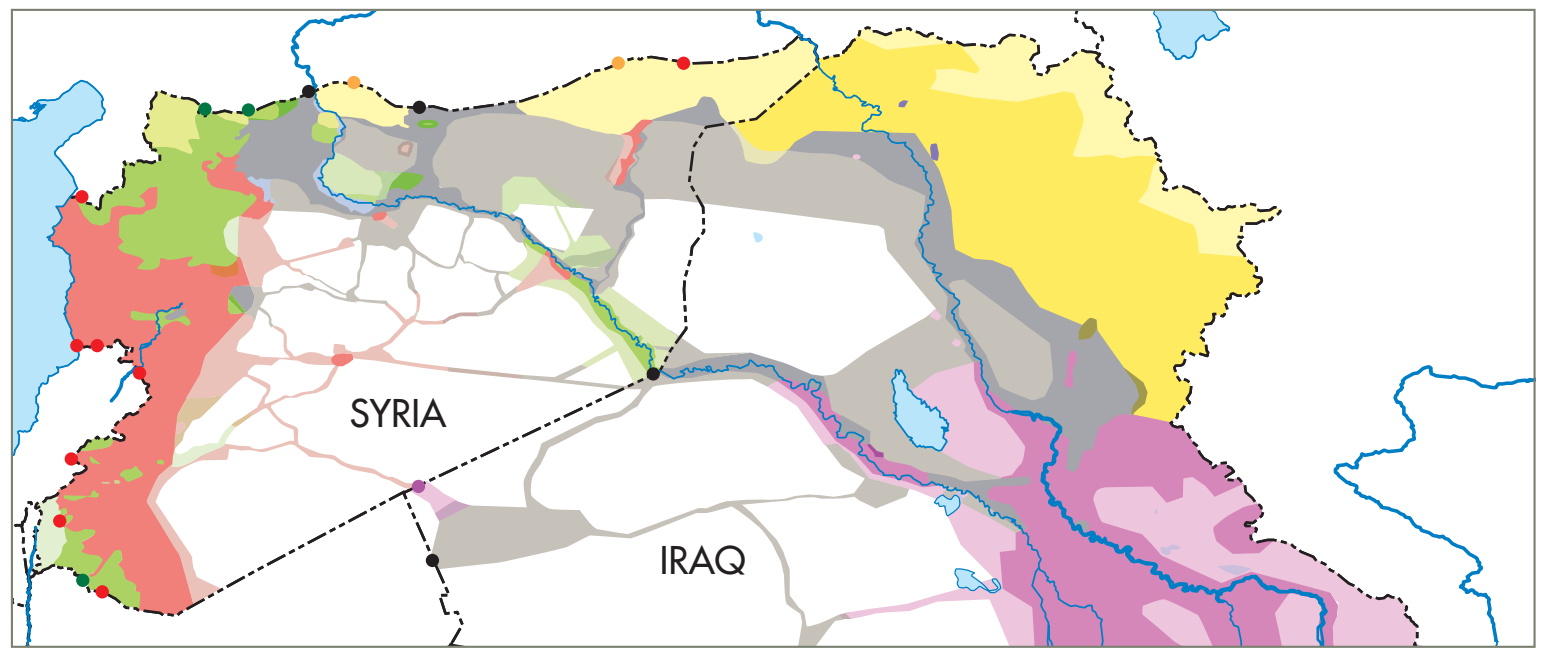

\section{Areas of control}

Low $\mid$ High

Syrian government and allies

Syrian rebels (FSA, IF, JAN, ...)

ISIS and allied tribes

Kurds (YPG, PICK, Pesmergas, ...)

Iraqi governmen

assyrians

Disputed or unclear

$\ldots$ Border crossing 
biological or other weapons of mass death to use in attacks against New York [or] Washington," or that there was "a very real possibility" that ISIL forces may already have crossed the U.S.-Mexican border. ${ }^{7}$ This was shock and awe in reverse.

On August 8, American aircraft bombed ISIL artillery positions and other targets around Sinjar and Erbil to protect fleeing Yazidi refugees and American citizens who had taken refuge in Erbil. This was a humanitarian intervention justified by the principle that those who can prevent slaughter are obliged to do so. It did not reflect a decision to become Iraq's air force, although further bombings were carried out to prevent ISIL from overrunning a key dam in northern Iraq. The mission of preventing massacres and protecting American citizens was soon broadened to degrading and defeating ISIL.

Pressure on the administration for military action had been building for months. Critics of President Obama saw ISIL's growing power as a direct consequence of America's failure to negotiate a deal with the government of Iraq that would have maintained a residual American force in Iraq beyond 2011, and the decision by the President not to intervene earlier in 2012 to assist Syria's secular rebels when this was viewed as a viable possibility by many. ${ }^{8}$ Some saw the Islamic State as a new Afghanistan-a launching pad for future terrorist attacks on the United States. The future threat to Western security posed by ISIL's foreign fighters had been a recurring theme at the Aspen Security Forum in July, where a growing consensus among U.S. security specialists on the necessity for preemptive U.S. military action was evident. On September 14, South Carolina Senator Lindsey Graham warned, “This president needs to rise to the occasion before we all get killed back here at home." 9
Dismayed by the poor performance of Iraq's Americantrained army and fearing the further collapse of its defenses, the United States indicated its willingness to increase assistance to Iraq, as Iran was already doing, but not to an Iraq with the demonstrably ineffectual government led by Nouri al-Maliki, who was still in power. Maliki was held responsible for both Sunni discontent and Iraq's military failure. To defeat ISIL would require the cooperation of the Sunnis. Facing international and domestic political pressure, including pressure from some Shia leaders, Maliki resigned in August and was replaced by Haider al-Abadi, who, it was hoped, could take actions that were more inclusive of both the Sunni and Kurdish segments of the population. Whether the new regime would in fact be willing and able to do this remained a question, but after nearly a year in office, it had made little progress.

Meanwhile, the United States assembled a coalition of Western and Arab countries that were willing to participate, or at least assist, in an air campaign that would "degrade, and ultimately destroy, ISIL.” The campaign, which began in September, was expanded to include jihadist targets in Syria. At the same time, the United States initiated a new program aimed at rebuilding and training portions of a new Iraqi army comprising Shia, Kurdish, and Sunni brigades, and it committed itself to the creation of a new rebel force in Syria that would be able to recapture territory held by jihadists.

Progress in mobilizing and training fighters in Syria who would be able to challenge the jihadists, especially those of ISIL, proved to be exceedingly slow, with little prospect of creating an opposition force with the size and capabilities necessary to achieve the stated goals. Although the force was initially envisioned as an 
army of 5,000 — already too small to be a contender in the conflicts—by July 2015, only 60 fighters had started to be trained by the United States. ${ }^{10}$

These efforts did not satisfy those who believed that ISIL could not be destroyed without the deployment of American combat forces on the ground or, at a minimum, embedded advisors and air-to-ground controllers who could significantly enhance the utility of airpower when supporting forward elements of Iraqi and Kurdish Pesh Merga forces. Others wanted the United States to increase its efforts to bring down the Assad regime. Debates about strategy continued.

\section{Syria's Brutal Engrenage}

Developments in Syria during 2014 were much more complicated than those in Iraq. Both government and rebel forces recorded gains and losses. The most significant development was the Syrian government's demonstrated ability to survive and gradually recover some ground. Supported by Hezbollah and Iranian-trained militias, Syrian forces recaptured Hama and Homs, a number of key towns along the border with Lebanon, and portions of Aleppo. This was part of a campaign to cut off rebel supply lines from Lebanon

\section{Syrian government forces continued to rely on aerial and artillery bombardment, which caused heavy casualties and massive destruction}

and consolidate control over western Syria, where the bulk of the population and almost all government loyalists reside.

Syrian government forces continued to rely on aerial and artillery bombardment, which caused heavy casualties and massive destruction. Unable to match the government's heavy firepower, the rebels used their own artillery to shell cities and carried out massacres and indiscriminate bombings. In 2014, 76,000 people died in Syria, bringing the civil war's total number of deaths to more than 200,000. ${ }^{11}$ The number of Syrian refugees fleeing the country or internally displaced climbed to somewhere around 50 percent of Syria's total population. ${ }^{12}$

ISIL launched attacks in several parts of the country and managed to take some key Syrian military bases and governmentheld towns. The group also was able to consolidate its position in eastern Syria and along the Euphrates River. In August, it moved against the Kurdish enclave in northern Syria but was prevented from taking the important city of Kobani, on Syria's border with Turkey, by coalition air strikes and a reinforced Kurdish defense that, for the first time, included Iraqi Pesh Merga. Despite suffering heavy losses, ISIL forces continued to launch attack after attack on Kurdish positions and tenaciously defended their positions against Kurdish counterattacks. Although the ISIL fighters were ultimately pushed back, the battle of Kobani suggested that retaking cities and towns held by ISIL in Syria and Iraq will require costly house-to-house fighting.

While the combined forces of Syrian, Turkish, and Iraqi Kurds have made significant progress in northern Syria, President Erdogan of Turkey has threatened to use Turkish forces to prevent further Kurdish advances out of fear that this success will lead to future calls for Kurdish independence. 


\section{The Weakness of the Non-Jihadists}

Fighting among the rebel forces_-in particular between ISIL and the other rebel formations, the most powerful of which was JANcontinued throughout the year. Between 5,000 and 10,000 rebels were killed in these armed clashes, which were accompanied by assassinations of commanders on both sides and smaller formations switching sides. There were attempts to end the internal conflict through mediation, but hostilities continued.

There were also several attempts, some externally inspired, to create united fronts that would fight against both the Assad regime and ISIL. Rather than achieving strength through union, these coalitions reflected the continuing disarray and growing weakness of the non-jihadist rebel formations.

The principal loser among the rebels in 2014 was the Free Syrian Army (FSA), an assemblage of moderate and secular forces favored by the West. Beset by defeats and defections, the FSA lost ground throughout the year. By year's end, it was pushed back by JAN forces in Idlib and confined to small footholds in northern and southern Syria and was considered in danger of disintegration, with surviving components existing only at the sufferance of JAN. By the middle of 2015, the FSA had virtually disappeared, its fighters having joined the more religiously motivated formations in Syria. This was bad news for the United States, which had supported the FSA rebels.

Despite all the death and destruction, Syria's map changed little. Neighborhoods changed hands, but provinces did not. The year ended in a stalemate. Without external assistance, the rebels cannot bring down the Iranian- and Russian-supported government through military force. The government has managed to drive rebels out of portions of its western enclave and expand its control into adjacent areas, but it cannot realistically hope to defeat the rebels, particularly the jihadist groups that control much of the country, especially the countryside in eastern and central Syria.

\section{The Pattern of Fighting in 2015}

With some notable exceptions, the same pattern of fighting continued in 2015. Syrian government forces, which showed resilience in 2014, suffered serious losses in the first half of 2015. In the northwestern part of Syria, military offensives by JAN and other smaller rebel formations took over the cities of Aleppo and Idlib, the important al-Mastumah army base, and most of the surrounding towns. This gave the rebels control over much of Idlib Province and put them within artillery range of Jericho. At the same time, the salafist-dominated southern rebel front seized a number of towns in southwestern Syria, setting up a major battle between the rebels and Hezbollah units fighting on behalf of the regime.

Meanwhile, fierce resistance and American bombing thwarted ISIL's attempt to take over Kobani, and buoyant Kurdish fighters were able drive ISIL out of several more towns in the surrounding area. Kurdish fighters were also able to drive ISIL out of towns in northern Iraq. In addition, Iraqi government forces and Shia militias, with, importantly, the last-minute but crucial assistance lent by U.S. airpower after Iranian assistance proved incapable of dislodging ISIL forces, were able to retake Tikrit, a major achievement that was soon overshadowed, however, by the loss of Ramadi.

Despite these setbacks, ISIL was able to further consolidate its control of Raqqa Province in eastern Syria and to threaten the 
ancient city of Palmyra and the adjacent Syrian Tadmur airbase. Some sources credited ISIL with control of 50 percent of Syria's territory. ${ }^{13}$ "Control" may be an overstatement. ISIL occupies some towns, exercises influence over neighboring populations, and can move freely (except for its ever-present exposure to air strikes) through these areas. Maps that show great swaths of land in ISIL hands are misleading. Much of the land mass conceded to ISIL control is empty desert, part of the great desert that extends across northern Saudi Arabia, western Iraq, and southern Syria, vir- tually uninhabited except for nomadic herdsmen. What ISIL really controls is the Euphrates River Valley, which crosses Syria and Iraq and includes the river towns of Raqqa, Ramadi, and Fallujah.

The Euphrates River is the key geographical feature of the landscape and has enormous economic and strategic importance. Upstream dams have restricted the flow of water in recent decades, while overfarming has stretched scarce water supplies. Many residents of the Euphrates Valley were displaced by dam projects, and those remaining have suffered severe hardship, no doubt contribut-

Figure 2. Syria and Iraq, June 25, 2015.

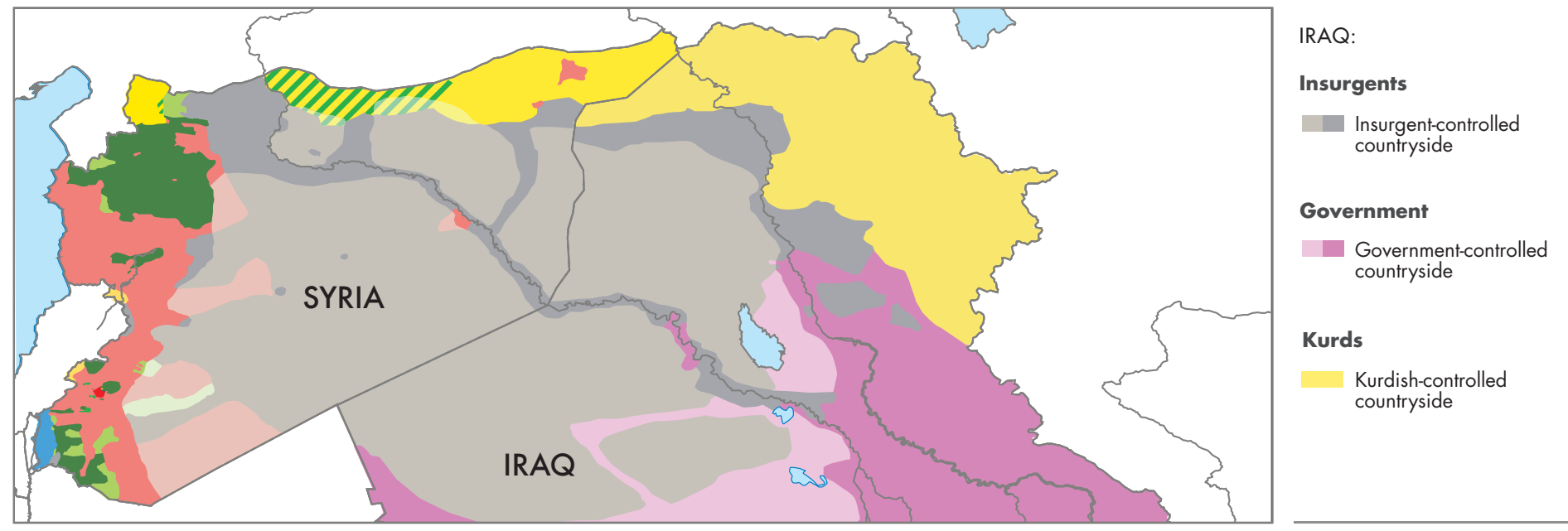

SYRIA:

\section{Rebels}

Low $\mid$ High

Rebel-controlled countryside

Mixed rebel/Jihadi-controlled countryside

\section{Loyalists}

Loyalist-controlled countryside

Hezbollah-controlled countryside

\section{Rojava}

Kurdish-controlled countryside

\section{Foreign forces}

Islamic State-controlled countryside

Israeli-controlled countryside 
ing to the discontent that ISIL has been able to exploit. The situation was exacerbated in 2014 by Turkey's decision to cut off the flow of water into Syria. Dams on the Euphrates and Tigris rivers are also important military targets, enabling those in control to cut off water or to flood areas downstream.

In May 2015, after a year-long battle with Iraqi forces, ISIL forces were able to capture the entire city of Ramadi. The fall of Ramadi demonstrated the ability of the group to adapt to the air campaign against it and to maneuver and mass its forces to shape the battleground for a decisive victory. It also showed ISIL's ability to move forces back and forth and carry out simultaneous offensives on both its western and eastern fronts. In addition, the capture of Ramadi underscored the weakness of Iraq's army.

Ramadi's fall to ISIL, followed quickly by ISIL's capture of Palmyra in Syria, had great psychological significance, coming after optimistic briefings in Washington had announced that ISIL's operational capabilities were being seriously eroded by the continuing air campaign. That may have been true: ISIL's victory in Ramadi may have been extremely costly. However, ISIL appears to have a large supply of volunteers_-paradise-seeking fanatics who are expendable to ISIL.

Contemporary warfare is not just about battles. It is about the manipulation of perceptions. In order to attract recruits and discourage its foes, ISIL has to appear to be winning, while its foes must appear to be losing. At Ramadi, the Iraqi army failed, and the American-led bombing campaign looks as if it has failed, regardless of what actual progress it has made in weakening the organization.

\section{Looking Ahead}

While all predictions are perilous, I believe that the attributes of the current conflicts will shape the future of the region in a variety of ways, militarily and politically. Here are nine fundamental conclusions.

\section{The Conflicts Are at a Stalemate}

Although the fighting in Syria and Iraq continues on multiple fronts, the conflicts are essentially at a stalemate. With few exceptions, the map of the conflicts in the two countries does not look dramatically different from that of almost a year ago, when initial tactical victories by the Kurdish and Shia militias pushed ISIL out of northern and eastern Iraq. While Iraqi forces subsequently freed Tikrit, they lost Ramadi.

The Assad government appeared about to fall in 2013 and recaptured some towns in 2014, but now it again appears weak. Government forces cannot defeat the rebellion and retake Syrian territory now held by rebel fronts in the west and ISIL in the east. Nor can the rebel formations defeat the government or overrun and subdue its loyalist strongholds in western Syria.

Rebuilding the Iraqi security forces will take years. Even with Iranian support, the Iraqi army, for the foreseeable future, will not be able to dislodge dug-in ISIL fighters from the urban areas they now hold. ${ }^{14}$ Moreover, should the government of Iraq turn to the Shia-dominated Popular Mobilization Forces that have been trained, organized, and equipped by Iran to recapture Sunni towns and villages, it is likely to result in an intensification of the sectarian conflict and lead to greater long-term instability in Iraq.

ISIL will continue to dominate Iraq's Anbar Province and the adjacent part of eastern Syria, but it has reached a sectarian 
boundary. It has found a measure of support in Sunni territory, which was a bastion of resistance during the Iraq War, but it will find it much more difficult to seize and hold majority-Shia areas in Iraq. Some towns may fall, but ISIL will not be able to replicate its 2014 sweep across northern Iraq. However, it will be able to challenge other jihadist groups for territory in Syria. A longer-term question is whether ISIL will be able to effectively govern the areas it now controls other than through intimidation and the provision of limited services. The same question applies to the areas under JAN control.

ISIL can infiltrate sleepers into Damascus and Baghdad and can carry out terrorist attacks - a large-scale Mumbai-style attack or even an urban offensive. The latter might look like a smaller version of the Viet Cong's 1968 Tet Offensive in Vietnam. That offensive was not meant to capture and hold Saigon or Hue but instead was aimed at seizing key points in the cities and holding them for weeks, thereby indicating that American military might had failed to defeat the Viet Cong. The Tet Offensive cost the attackers dearly-the Viet Cong was destroyed as a fighting organization—but it broke America's political will. Such an attack in Damascus or Baghdad could topple the current political leaders, but they would be replaced and the fighting would continue.

ISIL itself and its supporters are likely to escalate their terrorist campaign against Shias and symbols of the Shia faith across the region, certainly in the Shia portions of Iraq but also in Saudi Arabia, Kuwait, and potentially other Gulf monarchies.

Kurdish fighters, augmented by coalition airpower, are able to defend their autonomous territory in northern Iraq and Syria, but they are unlikely to be able to make dramatic inroads into ISIL-held territory. Any advance to the south would put the Kurdish fight- ers into Sunni territory, where they could also face resistance from Sunni tribes. Nor do the Kurds want to hold larger swaths of territory, especially given Turkish opposition. The Kurds have exactly what they want-domination of the territory from Kirkuk north to the Turkish border. But their cooperation with Baghdad to take Mosul will be essential if that operation is to succeed.

In Syria, JAN and rebel formations have now held most of their territory for a long time. As in Iraq, towns have changed hands between the government and the rebel forces and between the rebels and ISIL. The conflicts are increasingly a "war of edges." Consolidation will occur, along with expansion and erosion, but gains and losses will be incremental.

\section{Sectarian and Ethnic Differences Are Now Driving the Fighting} The conflict in Syria has become almost entirely sectarian as secular opposition to the government has eroded, although some Sunnis are still fighting on the side of the government forces, creating internecine conflicts among them. Another internecine conflict is that between JAN and ISIL, both dominated by Sunnis. In Iraq, the lines between Sunni, Shia, and Kurds are more clearly drawn.

Sectarian fault lines limit military advances, and they also affect the composition of the national armies. Governments with much of their territory in insurgent hands are unable to recruit or conscript on a national basis. Sunni areas are beyond their reach, and Syria's Alawite-dominated government and Baghdad's Shia-dominated government deem Sunni recruits to be unreliable anyway. Syria will continue to rely on Alawites and some local Sunnis. This situation is making the national armies less and less representative of the national populations and more and more sectarian formations. The trend is accelerated by the reliance of both Damascus and Baghdad 
on militia units, which are organized exclusively on sectarian or ethnic lines. (More on this below.) It will be difficult to reverse this trend without recapturing much of the national territory and making determined efforts at political outreach. Such actions seem unlikely.

On the other side, secular rebel formations have been ground out of existence. Insurgencies in both countries are primarily Sunni. Former fighters of the FSA who have joined more religiously motivated groups in Syria may be increasingly radicalized (or must pretend to be so for survival).

Sectarian differences will continue to impede Iraq's Shia-led government's willingness to make meaningful efforts to reconcile with the Sunnis or take actions to fulfill promised concessions to the Kurds-efforts that will be necessary to create a genuine national effort against ISIL. There is no evidence of any Syrian government effort to win Sunni hearts and minds. That is contrary to Syria's counterinsurgency strategy, which has the goal of making life untenable in areas beyond government control, turning large portions of the population into refugees.

The demonstrated brutal behavior of ISIL occupiers toward religious and ethnic minorities makes the defense of Shia, Alawite, Christian, Druze, and other minorities a matter of life and death. At the same time, the behavior of Assad's Alawite loyalists and Baghdad's Shia militias in towns they capture contributes to a cycle of revenge, retribution, and forced relocation-the struggle has become an existential one for all parties involved.

The sectarian nature of the conflicts has two further consequences. First, it impedes assistance from the United States and its coalition partners. While they aim to destroy ISIL and, to a lesser degree, bring down Assad, they cannot support the brutal sup- pression of the Sunnis. Second, sectarian differences will prevent an overall settlement of the conflicts. When the rebellion in Syria was still primarily about removing Assad, a political settlement may have been possible. That is no longer the case. And while the United States seeks to persuade the government of Iraq to take the actions necessary to reconcile with the Kurdish and Sunni minorities, peace has a price that neither Shia, Sunni, nor Kurd appears willing to pay. No sectarian group can envision living under the domination of another.

\section{National Armies Have Failed-Power Has Shifted to} the Militias

In both Syria and Iraq, large standing national armies failed to suppress internal rebellions. As protests in Syria escalated to armed resistance, large-scale desertions by Sunni conscripts made Syria's ground forces unreliable, forcing the government to abandon sections of the countryside to the rebels and to depend on its more-reliable air force, artillery units, and elite forces dominated by loyalists. A large number of irregular Shia militias from Iraq and Lebanese Hezbollah, all armed, trained, and equipped by Iranian Quds forces who fought alongside them, joined forces to fight alongside of the Syrian military. For reasons already discussed, the loss of territory and of access to a significant portion of the population that had been turned into refugees reduced the recruiting base for the national army, obliging the government to depend even more heavily on Alawite recruits for the regular army and to turn to hastily organized local militias. There are reports that even the government's Alawite base is growing weary of the burden. 
In Iraq, an army of nominally 350,000 men that had only recently been organized, equipped, and trained by the United States proved unable to halt the advance of a lightly armed irregular force less than one-twentieth its size.

While American air support blunted ISIL's subsequent assaults, the Iraqi government was forced to depend on militias mobilized by Shia clerics, politicians, and warlords who had close ties to Iran, many of whom fought alongside Iran during the Iran-Iraq war of the 1980s, to man its defenses. In 2015, a combined force of Shia militias, some Sunni tribesmen, and a small contingent of regular army forces was able to recapture some towns and the important city of Tikrit, but it was unable to hold on to Ramadi. Without substantial Sunni support, Iraqi forces will not be able to recapture control of Anbar Province.

With American assistance, the Iraqi army is under reconstruction, but it will not be ready for many months to attempt the difficult task of retaking Mosul and other important urban centers currently held by ISIL. One of the biggest challenges to training this force is gaining volunteers willing to undergo training. This is especially true of Sunni volunteers, many of whom remain unwilling to support a government they view as being a puppet

The shift in military power from regular forces under central control to semiautonomous militias has both military and political consequences. of Iran. Until that time, Iraq will remain dependent on the militias to protect Baghdad. The country's police forces are primarily dedicated to manning roadblocks and checkpoints to prevent the infiltration of terrorists and sleepers into Baghdad and other government-held areas.

The shift in military power from regular forces under central control to semiautonomous militias has both military and political consequences. Militias can defend local enclaves, but they cannot operate strategically. Internal quarrels are common. Unity of command is difficult to maintain. Militias lack training, heavy weapons, and mobility, although ISIL, an irregular force, seems to have overcome these challenges and appears increasingly able to coordinate large-scale offensives, carry out shaping operations, and mass forces for decisive battles. ISIL has made up for its lack of heavy weapons by innovations such as using massed armored bulldozers (and U.S.-provided Humvees) to carry out suicide vehicle-bomb attacks, as it did with devastating effect in Ramadi. This suggests some skill and experience derived from large-scale warfare, which former Iraqi officers are providing. The fall of Ramadi has given ISIL a significant amount of heavier equipment. Militias also are hard to control and, especially in sectarian fights, are prone to carrying out reprisals, pillage, and ethnic cleansing. ISIL does not worry about such behavior-instead, it uses it to terrorize its foes and attract foreign recruits.

The growing government reliance on Shia militias also poses a long-term threat to the survival of an independent Iraq with a government capable of governing the entire country. One of the key characteristics of a functioning state is having a monopoly on the use of force. In the case of Iraq, Shia militias since 2004 have 
effectively served as a shadow government, where government officials exercised control over the militias with familial ties, all of which were supported by Iran. This has resulted in a weak central government that is highly susceptible to Iranian influence in its internal affairs. This is similar to the situation that currently exists in Lebanon, a fact that has led many Iraq experts to call this the "Lebanonization of Iraq."

The Syrian government faces problems similar to those in Iraq, although the situation in Syria is more complex and Syria is further along the road to ruin. Syria's army and air force can use force strategically to destroy commerce, food production, and health care in rebel zones, but it relies on militias to defend loyalist enclaves. The militias have limited strategic effectiveness and ability to project power. The government will not be able to drive the jihadists out of territory that they have now held, in some cases, for several years.

The shift of power from central armies to militias also means weaker central authority. The government no longer exercises a monopoly on large-scale violence. Government forces can carry out destructive attacks to the limits of national frontiers, but they cannot conquer or control the national territory. Political power devolves to local forces that pursue their own political and sectarian goals_rebel formations and local militia commanders, some of whom owe loyalty to foreign powers, warlords, or mafias. Reunification and the imposition of national authority would imperil the status of local chieftains, sectarian agendas, and, in some cases, lucrative enterprises that emerge in the absence of central authority.

Until recently, Syria and Iraq have been ruled by men who killed their way to the top and maintained national unity and their own power by creating large armies and pervasive internal security apparatuses and by ruthlessly suppressing all dissent. Diminished central power-both armed force and the ability to distribute spoils_-may mean a return to the instability that was present in both countries during the 1950s and 1960s. Between 1949 and 1970, Syria saw numerous plots and seven coups, which ultimately put Hafez al-Assad into power. Iraq saw three coups between 1958 and 1968, culminating in the ascension of Saddam Hussein.

\section{Syria and Iraq Have Ceased to Exist as Nations-the Partitions Will Persist}

Both Syria and Iraq are artificial creations, their borders laid out by colonial mapmakers with little knowledge of or attention to ethnic and sectarian realities on the ground. Colonial rule kept them intact while exacerbating some of the tensions between ethnic and sectarian groups. The military dictatorships that followed independence crushed any ethnic or sectarian rebellions. The American invasion of Iraq and the rebellion in Syria sundered the bonds that held the countries together. The continuing conflicts have deepened these divides.

The increasingly sectarian nature of the conflicts and the erosion of central authority suggest that the de facto partition of both countries will persist. Syria and Iraq have ceased to rule their national territory and may never be able to do so. For the foreseeable future, neither country will easily be put back together.

A map of the territories dominated by the various belligerents roughly reflects a map of the distribution of ethnic and sectarian communities. Syrian government forces, combined with local militias and allied Hezbollah fighters, hold the Alawite and Christian bastions in the mountains of the so-called Djebel Ansariyeh and the Mediterranean coast, along with some outposts in 


\section{Figure 3. Syria and Iraq Ethnicity Density, 2015.}
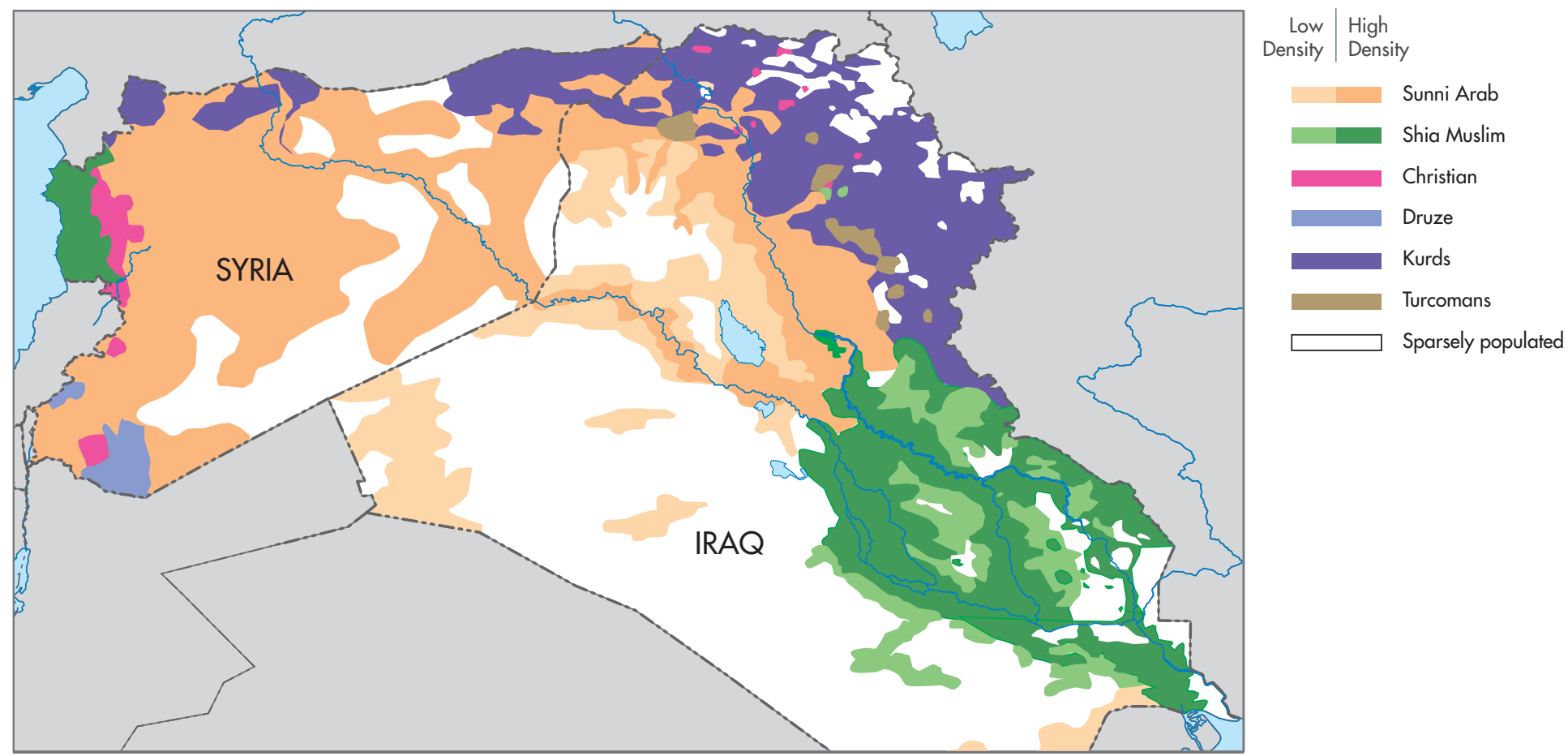

SOURCE: Unpublished paper by Amichai Ayalon, Robert C. Castel, and Elad Popovich.

more distant parts of the country. Exhausted by the fighting and short of manpower, pro-government forces may consolidate their defenses in this stronghold. The Kurds have succeeded in uniting and consolidating their hold on the Kurdish areas of Syria and Iraq. Iraq's Shias remain dominant in eastern and southern Iraq, their traditional territory. ISIL in western Iraq and eastern Syria and other rebel forces in the western part of the country dominate the Sunni areas. ISIL overextended itself in 2014 and was pushed back. Meanwhile, ISIL and other rebel forces in Syria inch forward around Damascus and Idlib but appear unable to deeply penetrate Syria's Alawite and Christian heartland.

Iraq will remain partitioned into Shia, Sunni, and Kurdish zones, although the forces within these areas are not unified and some are engaged in intrasectarian fighting. Syria, likewise, will remain divided into a more-complex mosaic of ethnic and sectarian enclaves mostly defended by local forces. Although still 
beset with internal rivalries, the Kurds, especially those in Iraq, will remain virtually independent, as they have been since the Gulf War.

Whether these ethnic and sectarian subdivisions are economically viable is another question. One can see the outlines of a Syrian rump state comprising Damascus and the western Alawite, Christian, and Druze enclaves. It would correspond roughly to the old Ottoman vilayet of Syria. Oil revenues would support a Kurdistan comprising portions of Syria and Iraq. Likewise, the Shia portion of Iraq would have ample resources from oil. A Sunni entity in the Euphrates Valley and scattered in the Syrian-Arabian Desert would appear to be primarily an agricultural community and potentially the most impoverished.

This situation poses a dilemma for the United States and others dedicated to the preservation of Syria and Iraq as they currently appear on maps. Today's frontiers, casually sketched by colonial officials in 1915, have little meaning on the ground today, but the suggestion that the current conflicts might be resolved by carving up Syria and Iraq into smaller states is seen by some in the Middle East as another Western imperialist plot. Those who subscribe to this theory believe that the Western powers, the United States in particular, are deliberately fanning the sectarian aspect of the conflicts to serve their own interests. ${ }^{15}$

Exhausted by war, the people of Syria and Iraq may someday, with international assistance, set aside their sectarian differences, turn against religious fanaticism, end the cycle of violence and retribution, and compromise upon a political structure that preserves nominal unity while allowing sufficient local authority and power-sharing to preserve peace. After 15 years of civil war, Lebanon achieved a tenuous but tolerable modus vivendi. The Lebanon timetable would suggest at least ten more years of hostilities, and Lebanon's civil war did not reach the intensity of the conflicts in Syria and Iraq.

Or perhaps some future Syrian or Iraqi version of an Ibn Saud or Kemal Ataturk, driven by dynastic ambition or nationalist fervor and possessing sufficient charisma, political savvy, and military skill, will be able to restore national rule in those countries. No such leader has yet emerged.

\section{Islamic State or Sunni Badlands?}

The Sunnis of Syria and Iraq face a bleak future under any scenario. Their discontent contributed to the rebels' military success, but what will that bring them in the long run? The moderate, secular, but mostly Sunni opposition in Syria has been ground away and is no longer a major force. That leaves it with no armed avatars other than the Islamists allied with the more extreme jihadists, and while there are other Sunni insurgent movements in Iraq, ISIL dominates Sunni resistance. Neither the Syrian rebel groups nor ISIL can conquer Syria and Iraq to install Sunni-led governments in Damascus and Baghdad. What, then, is the political future of the Sunni majority in Syria or a Sunni minority in Iraq? Could the Sunnis of the two countries unite to create an independent state that encompasses both western Iraq and eastern Syria?

\section{Today's frontiers, casually sketched by colonial officials in 1915, have little meaning on the ground today}


A key question is whether the Islamic State can continue to survive if its expansion is checked by sectarian boundaries and an effective defense on the ground backed by coalition airpower. The Islamic State's appeal depends on continued military victories, and its economy is based on plunder, which requires continued expansion. Its ability to fight has been clearly demonstrated, but not its ability to run a government and provide essential services, although it has now survived for a year and has occupied some territory for more than two years.

Western strategy is based in part on the presumption that continued ISIL control will inevitably alienate Sunnis and will ultimately provoke them to rise up against the organization, as they turned on al Qaeda insurgents during the Iraq War, but that may be wishful thinking. Whatever their attitude toward the extremists of the Islamic State, Iraq's Sunnis will be reluctant to join forces led by a Shia-dominated government or to rally to Americans as they did in 2006. Some Sunni tribes have taken on the Islamic State and suffered brutal reprisals. The Americans abandoned them once and are not there to protect them now. Turning against ISIL remains a risky proposition. Even if U.S. forces were there, it's unlikely that the Sunnis would once again place their trust in a country that many believe abandoned them by departing and leaving a government they argue is dominated by Iran.

To bring Iraq's Sunni tribes around a second time will require demonstrating that ISIL is losing and inevitably will be crushed, the Sunni tribes that rise against them can be protected against ISIL's retribution in the meantime, and Shia militias will not treat Sunnis liberated from Islamic State rule as collaborators and targets for plunder and revenge. None of those conditions can currently be met. Bringing Syria’s Sunnis around will require similar assurances of protection against ISIL reprisals and a better political future than that offered by the Assad regime.

Part of the American plan is to create a secular armed force in Syria that would be able to take on ISIL and the other jihadist groups, as well as the Assad regime-a more effective replacement for the ineffectual FSA. Under the circumstances, its fighters would be primarily, if not entirely, Sunni. The difficulties of vetting volunteers has stalled that effort, but even if the announced target of 5,000 fighters could be met, the force would still be a small contingent in conflicts where its foes field tens of thousands. With American air support, it could potentially defend an enclave in Syria to which Syrian refugees might be persuaded to return. This force was not initially envisioned as also fighting in Iraq, although it could do so.

To create a larger, more-powerful force will take a much greater investment and will involve some risks. But it can be done. In South Vietnam, approximately 2,000 U.S. Special Forces created an effective local defense and a counterguerrilla force of 50,000 fighters, mostly recruited from the region's mountain tribesmen. ${ }^{16}$ The Special Forces teams in the field did their own recruiting, and there was less concern about vetting — the Civilian Irregular Defense Group (CIDG), as it was called, by design took in some former Viet Cong, undoubtedly along with some infiltrators.

Overall, it worked. However, it took years, and there were setbacks. Camps were overrun. There were armed uprisings. The CIDG soldiers were far more effective on their own turf than in long-range operations. A more-limited effort to create such a force was made in Afghanistan. Potentially, it could work in the Middle East. Creating a large, effective Sunni fighting force could have political consequences. Political ambitions come with military 
power. A Sunni army could come to see itself as the vanguard of a Sunni state. That could complicate things.

Alternatively, the Sunni portions of Syria and Iraq could remain unassimilated and unpacified - a stronghold of religious fanatics, a continuing source of conflict, a permanent badlands

\section{Fighting Will Continue for the Foreseeable Future}

Under current circumstances, the idea of an international peace conference to end the fighting in Syria seems fanciful. Nor does it appear that the new Shia government will be able-or will even want- to reach a satisfactory political accommodation that will undermine Sunni resistance. The interconnected conflicts are likely to continue.

Neither side can defeat its foes. That would seem to incentivize a political settlement, but the increasing sectarian nature of the contest makes it a life-or-death struggle. The participants now fight to protect themselves against anticipated retribution and atrocities if they lay down their arms. No agreement can be enforced. No one can be trusted. For those motivated by their faith, compromise means apostasy.

Neither the fall of Assad nor the defeat of ISIL will end the hostilities. The wars in both Syria and Iraq are no longer two-sided contests. Syria's jihadist insurgents will not accept any government in Damascus other than one they create, and the jihadists themselves are at war with each other for control.

\section{At this time, it does not appear that any of the sectarian participants are willing to pay the price necessary for a durable peace.}

If it is swept from the battlefield and no longer able to operate openly, ISIL will continue its struggle in the form of guerrilla warfare and terrorist campaigns, as it and its predecessors have now done for more than a decade. ISIL's leadership could not order its fighters to lay down their arms, even in the highly unlikely circumstances in which it might want to do so. And if ISIL fragments under military pressure, there are other Sunni insurgent groups that currently cooperate with ISIL but will attract its fighters and continue the fight. No political deal will end this insurgency.

While national settlements seem unlikely, local accommodations are possible. These would entail not grand agreements but pragmatic understandings that lower the level of violence or permit commercial activity even while hostilities continue. At this time, it does not appear that any of the sectarian participants are willing to pay the price necessary for a durable peace. Fear and mistrust govern all of Iraqi politics. As Kurdish President Barzani stated in 2003, the Shia fear the past, the Sunni fear the future, and the Kurds fear both the past and the future. ${ }^{17}$

\section{Foreign Powers Have Much at Stake but Marginal Power}

Foreign powers have much at stake in the ongoing conflicts. But absent large-scale direct military interventions, which can easily backfire, none of the foreign powers can guarantee the triumph of their local allies or ensure the defeat of their foes. Moreover, the interests of the external powers compete with rather than complement each other. All might have at one time accepted a return to the status quo ante bellum, but that no longer seems possible.

Floods of refugees, along with jihadist infiltrators, threaten the stability of Lebanon and Jordan; in the eyes of ISIL's leaders, both are part of greater Syria and therefore within their immediate 
ambitions. Both countries want to keep the conflict from spreading to their territory.

Seeing itself as the protector of Sunnis against Shia aggression, Saudi Arabia opposes the Assad regime and the growing role that Iran is playing in the Syrian and Iraqi conflicts and in Yemen, where Saudis and Iranians are backing different sides in a civil war. At the same time, Saudi Arabia worries about the growing influence of jihadist extremists in Syria and Iraq and the threat they pose to the kingdom-ISIL could turn south.

Iran sees itself becoming the region's power, but with its strategic alliance with Syria threatened, its supply line to Hezbollah in peril, and its new friend in Baghdad under assault by Sunni fanatics, Iran could lose its vital footholds in the Arab world. As the sectarian component of these conflicts deepens, Tehran is assuming the role of protector of the Shias. If Iran has played a greater and seemingly more successful role since the uprising in Syria began, it is because it has more to lose and more cards to play.

Turkey remains determined to bring down Assad and supports the rebels. At the same time, it worries about the emergence of an independent Kurdish political entity in Syria and Iraq that will exacerbate separatist sentiments in Turkey. The growing threat posed by the jihadists and concerns about returning foreign fighters have pushed Turkey to moderate its support of jihadist elements.

Israel takes a practical view of things. The Assad regime provided the essential link between Iran and Hezbollah but kept the peace on Israel's border for 40 years. The Israelis saw Assad as a villain, but a prudent one. Far more dangerous to Israel's security would be a massing of out-of-control jihadists on its frontiers. Israel's principal concern, which has caused it to intervene mili- tarily in Syria on several occasions, is with preventing Iran from adding to Hezbollah's arsenal.

Many look to America to provide the decisive force, but the United States has remained cautious about its level of military involvement in the conflicts. It has provided various forms of assistance to the surrounding countries, principally Jordan. Material assistance to Syria's rebels has been slow in coming and modest, due to concern that American-provided weapons would fall into the hands of jihadists. The United States has led the air campaign against ISIL, which proved critical in preventing ISIL's advance against Kurdish-held areas in northern Iraq and the fall of Kobani in northern Syria. Aerial bombing has assisted Iraqi government forces, but it did not prevent the fall of Ramadi. Absent an effective force on the ground, airpower can weaken enemy attacks, but it cannot hold territory. Several thousand troops have been deployed to Iraq to protect U.S. diplomatic facilities in Baghdad and Erbil, to help coordinate operations, and to provide training, but they have no direct combat role. The United States has stopped short of putting "boots on the ground" to attack ISIL and has constrained direct U.S. involvement in counterterrorist efforts that had proved effective in reducing al Qaeda in Iraq in the period between 2005 and 2011.

This reluctance has provoked intense criticism of the government's strategy, which does not call for a significant military investment in what would be seen in the United States as the Third Iraq War. Critics argue that U.S. combat troops-estimates of the number needed range between 10,000 and 25,000_could bolster local defenses in critical areas, enhance the effectiveness of the air campaign, and inspire Iraqi units to fight harder. (Indeed, they might fight less, leaving it to the Americans to do the bloody work. ${ }^{18}$ The 
immediate presence of American combat units might also increase the chances that some Sunni tribes, restive under ISIL rule, would be enticed to turn against the Islamic State, but as mentioned previously, many may be reluctant to risk a second abandonment.

American units could also be used as a mobile strike force. A more ambitious and costlier task for American forces would be to drive ISIL forces out of the cities and towns they now hold. Urban warfare, especially against dug-in defenders, chews up armies. As we have seen on numerous occasions, from the battle of Hue in 1968 to the second battle of Fallujah in 2004, urban engagements can become ferocious fights. More than 13,000 American, British, and Iraqi forces were engaged in Fallujah, and they suffered nearly 1,000 casualties.

Controlling territory following the defeat of enemy forces would take a significant troop commitment, but clearing cities of ISIL forces, while leaving subsequent mopping-up operations and occupation to Iraqi forces (or Shia militias), risks associating the United States with the vengeance likely to be inflicted upon Sunni fighters and civilians, which the calculated brutality of ISIL has made almost inevitable.

Another possible mission for American combat forces might be to create protected enclaves for refugees. In 2012, John McCain,

\section{Many look to America to provide the decisive force, but the United States has remained cautious about its level of military involvement in the conflicts.}

Joe Lieberman, and four other senators called for the creation of "safe zones" inside Syria, where refugees could find safe havens and anti-Assad rebels could be trained and armed. ${ }^{19}$

All of these possible missions are fraught with risk. Direct American involvement could result in heavy casualties among U.S. troops and Iraqi civilians. It risks the ugly prospect of future beheadings of any Americans taken prisoner and, with it, increased pressures to escalate the fight. Greater American involvement will inspire terrorist recruiting and increase the threat of terrorist attacks abroad and in the United States. It risks the possibility that the United States will become involved in a long counterinsurgency campaign, complicated by the existence of an insurgent sanctuary in Syria, which will then require expanding military operations. It could lead to a long occupation and the loss of international support. Nor would such an intervention by the United States be welcomed by Iraq's Shias, who, with or without Iranian instigation, might renew their own hostilities against the American forces. While Americans currently support the bombing campaign, hard fighting on the ground could quickly reverse that support. ${ }^{20}$

\section{Foreign Fighters Will Continue to Pose a Global Threat} According to figures made public at the beginning of 2015, an estimated 20,000 foreigners had traveled to Syria and Iraq to join the resistance. Most joined jihadist groups, and after the schism between ISIL and the other jihadist groups, the majority migrated to ISIL. Of these, an estimated 3,400 came from Europe and other Western countries. ${ }^{21}$ Despite the bombing campaign directed against ISIL, volunteers continued to head for Syria and IraqFrance's prime minister suggested that by the end of 2015, as many 
as 10,000 volunteers will have gone from Europe to those countries. $^{22}$ The numbers are slippery, making it hard to assess whether the coalition campaign is slowing this flow; however, private discussions with German and French officials in June 2015 indicated that thus far there is no evidence that the number of Europeans going or seeking to go to Syria and Iraq has diminished. And according to the latest FBI estimates, the number of Americans going or attempting to go to Syria has also sharply increased. ${ }^{23}$

ISIL's recruiting emphasizes unlimited violence against any Sunnis it views as apostate, Shias who are viewed as apostate by definition, and non-Islamic infidels as proof of its fervor and authenticity. It has attracted a large number of foreign volunteers, enthralled by its extremist views and brutal practices. To ensure their continuing loyalty, ISIL reportedly enlists them in atrocities that will prevent their ever leaving the organization. These foreign fighters now make up a significant portion of ISIL's total strength, a powerful claque for its continued brutality. They have no incentive to end the fighting. Although some may be disillusioned, most can expect harsh treatment if they return home. There is no way backthey must continue to fight. Many, no doubt, will be killed.

If prevented by military pressure from operating openly, ISIL_or its successors — probably would continue its campaign underground, but foreign fighters cannot easily blend into the local population, especially a population that saw an advantage to turning against them. Most would not survive. A number of them might scatter across the planet, many to other jihadist fronts in Libya, Afghanistan, or the Caucasus, or to new fronts in North Africa and the Middle East. Western governments worry now that some of the fighters, sent by ISIL planners or bent upon revenge, will return to carry out terrorist attacks at home. Some Western

\section{Syrian refugees constitute one in four of Lebanon's total population; in Jordan, they are about one in ten}

officials suggest that it might be best if the foreign fighters were kept confined to the current conflict zone.

\section{Millions of Refugees Are Permanently Displaced}

More than 200,000 Syrians have died in Syria's civil war. Half of the country's population has been turned into refugees, with 4 million registered refugees abroad and 7 million internally displaced. ${ }^{24}$ (For comparison, of a total European population of 542 million in 1940, between 11 million and 20 million people, or as much as 4 percent of the population, were displaced by the fighting in World War II.) With continued fighting, the death toll and the number of refugees will continue to increase. It is a humanitarian catastrophe.

Syria's counterinsurgency campaign has deliberately destroyed commerce and the delivery of essential public services to areas not under government control. With no end to the violence in sight, return and resettlement will not be possible. At the same time, the capacity of the surrounding countries to permanently absorb 4 million refugees is limited. Close to 2 million Syrian refugees are in Lebanon and Jordan. Syrian refugees constitute one in four of Lebanon's total population; in Jordan, they are about one in ten. It is not simply a matter of stretching limited resources. Absorbing the refugees officially would alter delicate local sectarian and political balances. Meanwhile, their presence increases the risk that the Syrian conflict will engulf both countries 


\section{Implications for American Policy}

As indicated at the outset, this essay presents an assessment of the current situation. It is not intended to offer policy prescriptions. It does, however, raise some fundamental questions that policymakers must address.

The conclusions that the conflicts in Syria and Iraq are at a stalemate; that sectarian and ethnic divisions are increasingly driving the conflict; that the large standing armies of Syria and Iraq cannot suppress the challenges to their authority, and power has shifted to the militias; that the partitions in both countries will persist and national unity will not easily be restored; that the future of Sunnis under domination of the Islamic State, the Assad regime, or Shias in Baghdad or as an independent entity remains uncertain; that it must be accepted that the fighting will continue; that without a significant military investment, foreign powers (with the exception of Iran) are at the margin; that the thousands of foreign fighters attracted to jihadist banners pose a long-term threat; and that the millions of refugees generated by the conflicts will not be able to return as long as the violence continues hardly seem to be controversial.

Yet they are antithetical to American policy. The very idea of a military stalemate lasting years_-or decades_defies America's sense of progress. Secular, democratic governance and religious tolerance are deeply held values. The United States currently operates on the presumption that the sectarian divides can be bridged by governments that are willing to share political power and national resources.

U.S. policy also remains committed to national unity in Syria and Iraq-America's diplomats have little choice. Opposed to the alteration of borders by force and to the very existence of the

\section{The United States currently operates on the presumption that the sectarian divides can be bridged by governments that are willing to share political power and national resources.}

Islamic State, Washington cannot escape its commitment to unified states. Partition is hard to swallow. To endorse it is subversive.

In Iraq, the United States seeks to rebuild the armed forces so that they will be able to restore government authority throughout the national territory. In Syria, the United States seeks to replace the Assad regime with a government that will be able to defeat the jihadists and reunify the country. It has hopes that the Sunnis will turn against ISIL, but it has no concrete proposals that would be acceptable to the Shia-led government (and little promise of protection) to offer them.

The view that national unity is more likely to be achieved-if it ever is - and maintained only at the point of a gun is unacceptable. This is not to say that the role of the United States should be to supervise a new delineation of borders in the region, but the United States should be able to at least think about how it might deal with the current reality of statelets, which might last for decades, or how it might handle declarations of independence or attempts to reunify countries by brute force. What happens, for example, if the Kurds openly assert their independence or if Iraq's American-retrained army marches on them?

That efforts to peacefully resolve the conflict through international agreements and local political settlements are likely to 
fail is rejected in Washington. This mindset precludes creative thinking about local accommodations that might offer an incremental approach to reducing the violence. The world is witnessing an ongoing civil war between Shias, Sunnis, and Kurds, as well as among various factions within the Shia and Sunni communities. Violence continues because of fear of annihilation that will accompany defeat and domination by any side's current foes and by a quest for power and wealth among the leadership of each of the competing sects. Violence in both countries is also being fueled by external nonstate actors and neighboring states that are competing over regional power and influence. The sectarian divide is more than a competition between Sunnis and Shias, it is a quest for dominance by the Persians (Iran), Arabs (Saudi Arabia and Gulf States), Kurds, Ottomans (Turks), and, increasingly, Egypt given the situation in Yemen.

Every murder of an American citizen, every publicized atrocity, every tweet from ISIL fighters exhorting others to carry out attacks in the United States brings renewed political pressure on the administration to increase America's military involvement in the conflicts.

While strategists in Washington debate whether the bombing campaign is working and will suffice or whether American ground forces are necessary, it is heretical to suggest that the United States is at the margin of these conflicts. It could become another belligerent on the ground, a powerful one, but it is difficult to predict what impact this would have on the course of the conflicts and whether it would be positive or negative.

There is also the question of whether the United States is obliged to assist Syrian rebels or the government of Iraq. Does the fact that American forces invaded Iraq and overthrew Saddam Hussein oblige the United States to forever ensure Iraq's security? When American troops withdrew in 2011 - as a result of the failure of Prime Minister Maliki and President Obama to find a mutually acceptable way to maintain a residual force_-did they leave behind a warranty?

This brings up an even more fundamental question: Whose fight is this? There are those who argue that it is Iraq's war. The United States can assist to a degree, but if the Iraqis won't fight, the United States cannot fight for them.

Proponents of greater American involvement counter that the conflicts in Syria and Iraq have become extensions of the global campaign launched after $9 / 11$ — the United States must defeat ISIL and the other jihadist groups because they pose a direct terrorist threat to the United States. (President Obama accepts the extension as legal authority for U.S. military action, but not necessarily the entire premise that continuing military efforts against the global jihadist enterprise oblige the United States to increase its military involvement in Syria or Iraq.)

Those proponents also argue that the United States must fight in Syria and Iraq to protect its own vital interests, prevent the region from becoming even more dangerously unstable, preempt Iranian domination, demonstrate America's reliability as an ally, and display resolve to potential foes like Russia and China. Without challenging the view that America's power has been used mostly for good, these are imperial arguments.

Some Americans oppose any further U.S. military intervention in the Middle East's seemingly endless wars, which they argue is likely only to make matters worse. Presaging what may be a major debate in the 2016 presidential campaign, Senator Rand Paul has asserted that U.S. military efforts in Libya, Syria, and Iraq have contributed to ISIL's growing strength. ${ }^{25}$ 
Others fall between the arguments that America must go all-in to defeat ISIL or that America has exhausted its role in the Middle East and should stay out. They argue that the United States is obliged to encourage democracy, secular government, and human rights; to oppose brutal oppressors like the Assad regime and the Islamic State; to protect threatened minorities; to assist worthy allies; and to encourage political settlements, preferably through diplomacy, but, if necessary, through judicious and limited applications of military force. Exactly what constitutes a judicious application of military force is itself a subject to debate.

There are no easy choices for U.S. policy_no right or wrong answers. Each potential course of action carries with it a unique set of costs and risks. It is clear that it is impossible to address any of these issues in isolation. What is needed is a regional strategy that provides a possibility of securing and advancing long-term, enduring American interests. Such a strategy must include addressing the sectarian war in Iraq and Syria, the growing influence of ISIL, and the plight of the Kurds and other minorities, as well as the power relationships that exist between regional states. Without an overarching strategy detailing what the United States wants to achieve, the resources it is willing to devote to achieving those objectives, and the development of ways to use those resources - in concert with others-any policy choice is likely to address a symptom of the problem rather than the problem itself. That describes an ambitious agenda that may exceed the role the United States thinks it can realistically play and the level of resources the American public is willing to support.

Political debate may shape public opinion and ultimately government action, but it can obscure the complexity of the choices. It can also lead to a mismatch between rhetoric calculated to assuage public alarm and anger and blunt accusations of weakness and responses that are cautious and aim at avoiding plunging the country into costly and potentially disastrous military campaigns that the public will come to oppose. There is nothing new about this dilemma. It comes with the uniquely prominent role the United States plays in the world and is inherent in America's democracy. Nonetheless, national objectives must be based upon realistic assessments of the situation. Here, the distance between aspiration and reality seems great. 


\section{Notes}

${ }^{1}$ The Aspen Institute, Program of the Aspen Security Forum, July 22-25, 2015. As of September 4, 2015: www.aspensecurityforum.org/agenda/.

${ }^{2}$ See Brian Michael Jenkins, The Dynamics of Syria's Civil War, Santa Monica, Calif.: PE-115-RC, 2014; Brothers Killing Brothers: The Current Infighting Will Test al Qaeda's Brand, Santa Monica, Calif.: RAND Corporation, PE-123-RC, 2014; and When Jihadis Come Marching Home: The Terrorist Threat Posed by Westerners Returning from Syria and Iraq, Santa Monica, Calif.: RAND Corporation, PE-130-1-RC, 2015. See also Jenkins, "Iraq Observations," The Hill, website, June 19, 2014; "Further Observations on Iraq," The Hill, website, July 14, 2014; "Iraq Makes Strange Bedfellows," U.S. News \& World Report, July 15, 2014; "An Evil Wind," Slate, July 31, 2014; "Disrupting Terrorist Safe Havens," The Hill, website, August 18, 2014; "Islamic State's Risky Business," Bloomberg, website, August 28, 2014; "An Inconvenient War," The Hill, website, September 25, 2014; "What Are ISIS's Options Now?" The Hill, website, October 10, 2014; "What Could U.S. Boots on the Ground Do in Syria and Iraq?" Defense One, website, October 15, 2014; "Air Campaign Against ISIS Just Getting Off the Ground," The Hill, website, October 17, 2014; "Is Obama a Modern-Day Quintus Fabius Maximus?" Los Angeles Times, October 22, 2014; "When Jihadis Come Marching Home," The Hill, website, November 19, 2014; "Eight Lessons from the Charlie Hebdo Attack," Slate, January 23, 2015; "ISIS's Calculated Barbarity," The Hill, website, February 10, 2015; and "Inside the Terrorist Factory," The RAND Blog and www.GlobalSecurity.org, March 30, 2015. As of September 4, 2015: http:// www.rand.org/blog/2015/03/inside-the-terrorist-factory.html.

${ }^{3}$ I am indebted to Andrew Liepman, Rick Brennan, and Seth Jones for their helpful comments in the preparation of this paper.

4 "Department of Defense Press Briefing by Secretary Hagel and General Dempsey in the Pentagon Briefing Room," August 21, 2014, News Transcript, U.S. Department of Defense. As of September 4, 2015: www.defense.gov/transcripts/transcript. aspx? transcriptid $=5491$.

5 Jaime Fuller, "Eric Holder on threats from Syria: 'It's more frightening than anything I think I've seen as attorney general,"'Washington Post, July 13, 2014. As of September 4, 2015: www.washingtonpost.com/blogs/post-politics/wp/2014/07/13/ eric-holder-on-threats-from-syria-its-more-frightening-than-anything-i-think-iveseen-as-attorney-general/.

${ }^{6}$ Phil Cross, "Senator Inhofe warns of potential terrorist attacks on U.S. soil, "Fox 25-KOKH Oklahoma City, website, August 20, 2014. As of September 4, 2015: www.okcfox.com/story/26331734/senator-inhofe-warns-of-potentialterrorist-attacks-on-us-soil.
${ }^{7}$ Brent Budowsky, "Budowsky: ISIS poses nuclear 9/11 threat," The Hill, website, August 26, 2014. As of September 4, 2015: www.thehill.com/opinion/brentbudowsky/215603-brent-budowsky-isis-poses-9-11-scope-threat; Mike Lillis, "Perry: 'Real possibility' ISIS in US," The Hill, website, August 21, 2014. As of September 4, 2015: www.thehill.com/policy/international/215704-perryreal-possibility-isis-already-in-us.

${ }^{8}$ For a full discussion of the American withdrawal from Iraq, see Rick Brennan, "Withdrawal Symptoms: The Bungling of the Iraq Exit," Foreign Affairs, November/December 2014, pp. 25-36.

${ }^{9}$ Philip Bump, "Lindsey Graham: We need troops to fight Islamic State 'before we all get killed here at home,' "Washington Post, September 14, 2014. As of September 4, 2015: www.washingtonpost.com/blogs/post-politics/wp/2014/09/14/ lindsey-graham-we-need-troops-to-fight-islamic-state-before-we-all-get-killedhere-at-homel.

${ }^{10}$ Reporting Secretary of Defense Ashton Carter's testimony before the Senate Armed Services Committee, Jennifer Rizzo, "Carter: U.S. trains only 60 Syrian rebels," CNN Politics, website, July 7, 2015. As of September 4, 2015: www.cnn. com/2015/07/07/politics/united-states-training-syrian-rebels-ashton-carter/.

${ }^{11}$ Syrian Observatory for Human Rights, "76,021 people killed in Syria in 2014," January 1, 2015. As of September 4, 2015: www.syriahr.com/en/2015/01/76021people-killed-in-20014/. Syria's casualty figures are controversial and the Syrian Observatory for Human Rights is an opposition organization; however, a report commissioned by the United Nations High Commission for Refugees stated that by August 2014, there had been 191,369 "documented killings" (Human Rights Data Analysis Group, Updated Statistical Analysis of Documentation of Killings in the Syrian Arab Republic, August 2014. As of September 4, 2015: www.ohchr.org/ Documents/Countries/SY/HRDAGUpdatedReportAug2014.pdf).

${ }^{12}$ By December 2014, the United Nations High Commission for Refugees was reporting 11.6 million Syrian refugees, including 7.6 internally displaced persons. Syria's total population in 2013 was estimated to be 22.8 million (UNHCR, "2015 UNHCR country operations profile-Syrian Arab Republic," undated. As of September 4, 2015: www.unhcr.org/pages/49e486a76.html).

${ }^{13}$ Fox News, "ISIS controls 50 percent of Syria after takeover of Palmyra, activists say," www.FoxNews.com, website, May 21, 2015. As of September 4, 2015: www.foxnews.com/world/2015/05/21/isis-controls-50-percent-syria-aftertakeover-palmyra-monitoring-group-says/.

${ }^{14}$ I am aware that the survivability of the Islamic State remains a matter of heated debate. Some argue that the Islamic State must inevitably fail as a viable governing enterprise that controls territory; others are less certain. See Tim Arango, "ISIS 
Transforming into Functioning State That Uses Terror as a Tool," New York Times, July 21, 2015. As of September 4, 2015: www.nytimes.com/2015/07/22/ world/middleeast/isis-transforming-into-functioning-state-that-uses-terror-astool.html?_r=0.

15 “Arabs, Beware the 'Small State' Option,” Al Akhbar English, July 29, 2013. As of September 4, 2015, a slight variation of this article remained posted online at www.mideastshuffle.com/2013/07/31/arabs-beware-the-small-states-option/.

${ }^{16}$ Department of the Army, Vietnam Studies: U.S. Army Special Forces, 19611971, Washington, D.C., 1973. As of September 4, 2015: www.history.army. mil/books/Vietnam/90-23/90-23C.htm. See also Rebecca Onion, "The SnakeEaters and the Yards," Great Moments in Military History, Slate, November 27, 2013. As of September 4, 2015: www.slate.com/articles/news_and_politics/ american_military_history/2013/11/the_green_berets_and_the_montagnards_ how_an_indigenous_tribe_won_the_admiration.html. The author of the present essay served in the Fifth Special Forces Group's CIDG program in 1966-1967 and as part of the Long Range Planning Group in Vietnam, 1968-1969, returning to Vietnam in 1971.

${ }^{17}$ Emma Sky, The Unraveling: High Hopes and Missed Opportunities in Iraq, New York: Public Affairs, 2015, Chapter 9.

${ }^{18}$ Theodore Schleifer, "Lindsay Graham Calls for 10,000 U.S. Troops in Iraq," CNN Politics, website, May 18, 2015. As of September 4, 2015: www.cnn.com/2015/05/18/ politics/lindsey-graham-iraq-not-a-mistake-election-2016/; Kimberly Kagan, Frederick W. Kagan, and Jessica D. Lewis, A Strategy to Defeat the Islamic State, Washington, D.C.: Institute for the Study of War, 2014. As of September 4, 2015: www. understandingwar.org/sites/default/files/Defeating\%20ISIS_0.pdf.

${ }^{19}$ Josh Rogin, "McCain Resolution Calls for Safe Zones and Arming the Syrian Opposition,” www.foreignpolicy.com, website, March 28, 2012. As of September 4, 2015: www.foreignpolicy.com/2012/03/28/mccain-resolution-calls-for-safe-zonesand-arming-the-syrian-opposition/.
${ }^{20}$ Peyton M. Craighill, "Why Americans' Support for Bombing ISIS May Not Last," Washington Post, September 22, 2014. As of September 4, 2015: www. washingtonpost.com/news/storyline/wp/2014/09/22/why-americans-supportfor-bombing-isis-may-not-last/. Public opinion polls in early 2015 showed that a majority of Americans wanted U.S. ground troops to take on ISIS, but data from previous wars in Korea, Vietnam, Afghanistan, and Iraq show that this support erodes once the fighting begins. It is, however, not that simple. Much depends on the public's perceptions of the stakes and of progress in the war effort. This is an area where RAND has done a great deal of research. See, for example, Eric V. Larson, Public Support for U.S. Military Operations, Santa Monica, Calif.: RAND Corporation, RB-2502, 1996, and Eric V. Larson, American Public Support for U.S. Military Operations from Mogadishu to Baghdad, Santa Monica, Calif.: RAND Corporation, MG-231-A, 2005.

${ }^{21}$ Nicholas J. Rasmussen, Director of the National Counterterrorism Center, "Countering Violent Islamist Extremism: The Urgent Threat of Foreign Fighters and Homegrown Terror," testimony before the House Committee on Homeland Security, February 11, 2015.

22 "French Prime Minister Warns 10,000 Europeans Could Be in Iraq and Syria by Year's End," www.USNews.net, website, March 8, 2015. As of September 4, 2015: www.usnews.net/index.php/sid/230889591.

${ }^{23}$ Lindsay Dunsmuir, "Over 200 Americans have gone or tried to go to Syria to Fight: FBI,” Reuters, website, July 8, 2015. As of September 4, 2015: www.reuters. com/article/2015/07/08/us-mideast-crisis-americans-idUSKCN0PI2E320150708.

${ }^{24}$ UNHCR, “Syria Refugee Regional Response," Inter-agency Information Sharing Portal, website, August 29, 2015. As of September 4, 2015: www.data.unhcr. org/syrianrefugees/regional.php.

${ }^{25}$ Jesse Byrnes, "Rand Paul blames republican hawks for growth of ISIS," The Hill, website, May 27, 2015. As of September 4, 2015: www.thehill.com/blogs/ballot-box/ presidential-races/243171-rand-paul-blames-republican-hawks-for-growth-of-isis. 


\section{About This Perspective}

This essay is the fourth in a series of RAND Perspectives by the author that examine various aspects of the continuing conflicts in Syria and Iraq. This analysis attempts to get beneath the often-bewildering headlines to identify the underlying dynamics of the conflicts, to indicate how these will shape the future of the region, and to examine how they are driving perceptions of the threat elsewhere. It is an assessment of the situation and is not intended to offer policy prescriptions. However, it does note the distance between reality and the aspirations of American policy.

I wish to express appreciation for the thoughtful reviews of Rick Brennan, Andrew Liepman, and Seth Jones. As always, I am indebted to Janet DeLand for her excellent editing. This continuing line of independent inquiry would not be possible without the support of the RAND Corporation and its president, Michael Rich.

\section{About the Author}

Brian M. Jenkins is a senior adviser to the president of the RAND Corporation and author of numerous books, reports, and articles on terrorismrelated topics, including Will Terrorists Go Nuclear? (2008, Prometheus Books). He formerly served as chair of the Political Science Department at RAND. On the occasion of the ten-year anniversary of 9/11, Jenkins initiated a RAND effort to take stock of America's policy reactions and give thoughtful consideration to future strategy. That effort is presented in The Long Shadow of 9/11: America's Response to Terrorism (Brian Michael Jenkins and John Paul Godges, eds., 2011).

\section{Limited Print and Electronic Distribution Rights}

This document and trademark(s) contained herein are protected by law. This representation of RAND intellectual property is provided for noncommercial use only. Unauthorized posting of this publication online is prohibited. Permission is given to duplicate this document for personal use only, as long as it is unaltered and complete. Permission is required from RAND to reproduce, or reuse in another form, any of our research documents for commercial use. For information on reprint and linking permissions, please visit www.rand.org/pubs/permissions.html.

The RAND Corporation is a research organization that develops solutions to public policy challenges to help make communities throughout the world safer and more secure, healthier and more prosperous. RAND is nonprofit, nonpartisan, and committed to the public interest.

RAND's publications do not necessarily reflect the opinions of its research clients and sponsors. RAND ${ }^{\circledR}$ is a registered trademark.

For more information on this publication, visit www.rand.org/t/pel63.

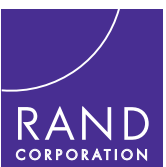

www.rand.org 